University of Michigan Law School

University of Michigan Law School Scholarship Repository

Law \& Economics Working Papers

8-16-2018

\title{
The Beat and Treaty Overrides: A Brief Response to Rosenbloom and Shaheen
}

Reuven S. Avi-Yonah

University of Michigan Law School, aviyonah@umich.edu

Brett Wells

University of Houston Law Center, bwells@central.uh.edu

Follow this and additional works at: https://repository.law.umich.edu/law_econ_current

Part of the Taxation-Federal Commons, and the Tax Law Commons

\section{Working Paper Citation}

Avi-Yonah, Reuven S. and Wells, Brett, "The Beat and Treaty Overrides: A Brief Response to Rosenbloom and Shaheen" (2018). Law \& Economics Working Papers. 157.

https://repository.law.umich.edu/law_econ_current/157

This Article is brought to you for free and open access by University of Michigan Law School Scholarship Repository. It has been accepted for inclusion in Law \& Economics Working Papers by an authorized administrator of University of Michigan Law School Scholarship Repository. For more information, please contact mlaw.repository@umich.edu. 
DRAFT 081618

\title{
THE BEAT AND TREATY OVERRIDES: A BRIEF RESPONSE TO ROSENBLOOM AND SHAHEEN
}

\author{
Reuven S. Avi-Yonah ${ }^{1}$ \\ Bret Wells ${ }^{2}$
}

In a recent paper posted on SSRN, Profs. David Rosenbloom and Fadi Shaheen argue that the Base Erosion Anti-Abuse Tax (BEAT) (IRC section 59A), as enacted in 2017, is a potential violation of Articles 23 and 24 of US tax treaties. In addition, they argue that the BEAT does not override those treaties and therefore the treaties can be relied upon to overcome the effects of the BEAT. As Rosenbloom and Shaheen conclude:

Courts generally seek to resolve apparent conflicts between the Code and the treaties. They are reluctant to approve a statutory override of negotiated treaty provisions even when a conflict is found. We believe they would be even less inclined to do so in the absence of some indication that Congress intended that result with respect to a statute enacted under a special reconciliation procedure that did not contemplate treaty overrides, with legislative history affirmatively indicating an intention not to override, and with nothing to the contrary in the statutory text. We believe that the BEAT's conflicts with the nondiscrimination provision and its reconcilable inconsistency with the foreign tax credit provision of U.S. treaties do not constitute treaty overrides. Therefore, for purposes of calculating the BEAT, deductions for otherwise deductible payments to related persons resident in treaty countries and foreign tax credits for foreign taxes paid to treaty countries should be allowed. ${ }^{3}$

In our opinion, this conclusion is wrong, for two reasons. First, we believe that the BEAT is not a treaty violation. Second, we believe that even if the BEAT were found to violate treaties, it is a treaty override.

\section{The BEAT Does Not Violate US Tax Treaties.}

As Rosenbloom and Shaheen argue, the BEAT potentially violates two articles of US tax treaties, article 23 (granting a foreign tax credit) and article 24 (non-discrimination). However, in our opinion neither provision is violated by the BEAT.

\footnotetext{
${ }^{1}$ Irwin I. Cohn Professor of Law and Director, International Tax LLM, the University of Michigan.

${ }^{2}$ George Butler Research Professor and Professor of Law, University of Houston Law Center.

${ }^{3}$ Rosenbloom, H. David and Shaheen, Fadi, The BEAT and the Treaties (August 2018). Available at SSRN: https://ssrn.com/abstract=3229532 (emphasis added).
} 
Article 23 requires the US to grant a foreign tax credit for certain foreign taxes:

In accordance with the provisions and subject to the limitations of the law of the United States (as it may be amended from time to time without changing the general principle hereof), the United States shall allow to a resident or citizen of the United States as a credit against the United States tax on income applicable to residents and citizens:

a) the income tax paid or accrued to by or on behalf of such resident or citizen; and

b) in the case of a United States company owning at least 10 percent of the voting stock of a company that is a resident of and from which the United States company receives dividends, the income tax paid or accrued to by or on behalf of the payor with respect to the profits out of which the dividends are paid. ${ }^{4}$

The BEAT is a "limitation" of the foreign tax credit because it does not allow foreign tax credits against BEAT tax liability. Nor does the BEAT change the "general principle" of the foreign tax credit because credits in general are available for foreign taxes imposed on foreign source income. The BEAT instead imposes a US tax on US source income (the interest and royalties paid to the foreign related party). Since 1921, the US foreign tax credit has been limited to only foreign source income. ${ }^{5}$ No "general principle" of the foreign tax credit is violated when the BEAT is applied to protect the US corporate tax at source. ${ }^{6}$

What is more, the United Stated, for many years prior to the enactment of Section 59A in 2017, had interpreted a predecessor alternative minimum tax regime (old Section 59) that did not allow a foreign tax credit to be fully utilized to reduce the corporate alternative minimum tax liability. ${ }^{7}$ The IRS has had a longstanding position that old Section 59's limitation on

4 US Model Income Tax Treaty (2016), Art. 23.

5 See REVENUE ACT OF 1921, CH. 136, § 222(A)(5), 238(A), 904(A), 42 STAT. 227, 249, 258.

${ }^{6}$ Arguably, however, a "general principle" was violated by the elimination of IRC section 902, the indirect credit, and the substitution of a limited participation exemption. In our opinion this was a treaty override. Similarly, the limitation of the FTC to $80 \%$ of foreign tax under GILTI may be a treaty override. For a contrary argument see Shaviro, Daniel, The New Non-Territorial U.S. International Tax System, Part 1 (July 2, 2018). Tax Notes, Vol. 160, No. 1, July 2, 2018; NYU Law and Economics Research Paper No. 18-23. Available at SSRN: https://ssrn.com/abstract=3222660.

7 See I.R.C. §59a)(2)(A) (2004). 
the ability to utilize foreign tax credits under the predecessor alternative minimum tax regime were compliant with Article 23 because of the bolded language set forth above. ${ }^{8}$

The Tax Court has also held that the further restriction on the availability of the foreign tax credit relief under a generally applicable alternative minimum tax regime did not violate U.S. tax treaties. In Pekar v. Commissioner, ${ }^{9}$ the Tax Court held, inter alia, that the limitations on the availability of US foreign tax credit relief under old Section 59 did not violate Article 23's relief from double taxation provision under the U.S.-U.K. tax treaty. Relying on the bolded language set forth above, the Tax Court stated as follows:

Article 23 of the U.S.-U.K. treaty generally prohibits double taxation and provides to U.S. residents and citizens a credit against their U.S. income tax in an "appropriate amount". U.S.-U.K. treaty, art. 23(1). An "appropriate amount" is defined as that amount of tax paid to the United Kingdom, not to exceed the limitations provided by U.S. law for that taxable year. Id. One of the limitations for the 1995 taxable year was the foreign tax credit limitation of section 59. Therefore, the U.S.-U.K. treaty provides for the imposition of the tax credit limit, and the treaty and the Code may be harmonized and the limit applied to petitioner. ${ }^{10}$

In dealing with this language, however, Professors Rosenbloom and Shaheen are dismissive, stating that:

"It is possible, in other circumstances, to ponder the precise meaning of the quoted words, but there is no need to do that with respect to the BEAT. It envisions no statutory foreign tax credit at all, and that is surely inconsistent with the "general principle" of Article 23, whatever the contours of that principle may be."11

The error in their thinking can be demonstrated by the following hypothetical. Suppose that the BEAT had applied a tax rate equal to the regular corporate tax rate of $21 \%$ tax but then had provided that foreign tax credit relief could not offset more than 11 points of the tax computed under Section 59A. In that situation, the minimum tax under this hypothetical regime would have

${ }^{8}$ See FSA 200110019 (Dec. 6, 2001).

${ }^{9}$ See Pekar v. Commissioner, 113 T.C. 158 (1999).

${ }^{10}$ See Pekar v. Commissioner, 113 T.C. at 162 (emphasis added). The Tax Court has continued to rely on this reasoning in later decisions, thus representing a longstanding view. See Brooke v. Commissioner, T.C. Memo. 2000-194, 79 T.C.M. (CCH) 2206 (2000), aff'd 13 Fed. Appx. 7 (D.C. Cir. 2001).

${ }^{11}$ See Rosenbloom, H. David and Shaheen, Fadi, The BEAT and the Treaties at 3 (August 2018). Available at SSRN: https://ssrn.com/abstract=3229532. 
preserved residual U.S. taxation equal to $10 \%$ in all events, but "in form" this hypothetical regime allows foreign tax credit relief of some amount. In relevant part to this analysis, this hypothetical regime is functionally equivalent to what Congress enacted in Section 59A. Said differently, Section 59A provides a concessionary rate of tax but restricts further foreign tax credit relief that does provide a benefit under the corporate tax rate to save the US taxing jurisdiction over the tax liability computed under the concessionary rate of tax. The formalistic distinction does not change the substantive reality that more than half of the regular tax liability could be offset by US foreign tax credit relief. The Supreme Court recently applied such an functional economic equivalency argument in the foreign tax credit context in PPL v. Commissioner ${ }^{12}$ where the Supreme Court unanimously held that the substance of the impact of a foreign tax regime was to be considered to determine its import under US tax law. Under the logic employed by the Supreme Court in the PPL case, the Court should find that a US tax regime that provides for a reduced tax rate with no foreign tax credit relief is functionally similar to an alternative minimum tax regime that initially provides for a full rate of tax and partially disallows usage of credits. If the latter is acceptable as Professors Rosenbloom and Shaheen accept, then the former substantively equivalent regime is as well.

Thus, Professors Rosenbloom's or Shaheen's dismissiveness would only be relevant if Section 59A had applied an alternative minimum tax at the regular corporate tax rate of $21 \%$, and had denied US foreign tax credit relief in that situation, but again that is not what Section 59A does in fact or in substance. In our view, a court can easily understand the phrase "subject to the limitations of the law of the United States (as it may be amended from time to time without changing the general principle hereof" to mean that the usage of US foreign tax credit relief is subject to the provisions and limitations of US law of which Section 59A is included-just like the Tax Court has already done with respect to old Section 59 in Pekar v. Commissioner. The natural reading of Article 23 employed by the Tax Court in Pekar v. Commissioner harmonized old Section 59's application with US tax treaty obligations, and it is faithful to the intended flexibility that was intended to be retained by the United States under Article 23 to allow it to enact domestic limitations on the availability of US foreign tax credit relief without running afoul of Article 23.

In addition, as Rosenbloom and Shaheen explain, it is not entirely clear that the BEAT is a covered income tax for purposes of the treaties. The BEAT functions as an alternative minimum tax, and its base is different than

12 PPL v. Commissioner, 569 U.S. 329 (2013). 
that of the income tax (so that it would not be considered an income tax under IRC section 901, because it is not imposed on net income). ${ }^{13}$ This is what Mr. Barthold seems to have had in mind in his answer to the question whether the BEAT is a treaty override:

And I believe in particular you were talking about the proposed base erosion anti-abuse provision of the chairman's mark. And it is structured as an alternative tax compared to the income tax. So I think our view is that there is not a treaty override inherent in that design. ${ }^{14}$

Even if Chief of Staff Barthold believed the BEAT were a covered tax, he could well have believed that Section 59A is not a treaty override (as we so believe) because of the flexibility and authority retained under Article 23 to "subject [foreign tax credit relief] to the limitations of the law of the United States (as it may be amended from time to time without changing the general principle hereof)." Given the breadth of this language, it certainly is plausible to believe that Chief of Staff Barthold did not think a treaty

13 While the AMT has been considered a covered tax, e.g., in Kappus v. Commissioner, 337 F.3d 1053 (D.C. Cir. 2003), courts have not addressed this issue directly. In the UK, HMRC believes that the Diverted Profits Tax (which has a function similar to the BEAT) is not covered (and so cannot be overridden) by double tax treaties because it is not 'substantially similar' to corporation tax and the UK's domestic law does not apply double tax treaties to DPT. A further argument is that, as an anti-avoidance measure, DPT is consistent with the spirit and purpose of the UK's double tax treaties. See, e.g., Avi-Yonah, Reuven S., Three Steps Forward, One Step Back? Reflections on 'Google Taxes', BEPS, and the DBCT (May 24, 2016). U of Michigan Law \& Econ Research Paper No. 16-016; U of Michigan Public Law Research Paper No. 516. Available at SSRN: https://ssrn.com/abstract=2783858 or http://dx.doi.org/10.2139/ssrn.2783 858; Dan Neidle, The Diverted Profits Tax: Flawed by Design? 2015 British Tax Review 147 (2015).; Heather Self, The UK's New Diverted Profit Tax: Compliance with EU Law, 43 Intertax 333 (2015); Jonathan Peacock, U.K.'s Diverted Profits Tax: A Regime Much, Much Broader Than its True Target? 17 European Tax Service 4 (2015). 7 Sol Picciotto, The U.K.'s Diverted Profits Tax: An Admission of Defeat or a Pre-Emptive Strike?, Tax Notes International 239 (January 19, 2015); Paul Rutherford, The U.K.'s Google Tax- First Thoughts, 42 Tax Planning International Review 4 (2015); Luca Cerioni, The New "Google Tax": The "Beginning of the End" for Tax Residence as a Connecting Factor for Tax Jurisdiction? European Taxation 185 (May, 2015); Philip Baker, Diverted Profits Tax: A Partial Response, 2015 British Tax Review 167 (2015) (the writer advised HMRC on the compatibility of the DPT with EU law and tax treaties).

${ }^{14}$ Barthold, quoted in Rosenbloom \& Shaheen, supra. As explained below, this is not a statement of Congressional intent. 
override was necessary for the BEAT to apply. However, Professors Rosenbloom and Shaheen take from this single statement the idea that the BEAT cannot have an application that reduces the allowance of double tax relief, stating as follows:

Whatever [Mr. Barthold's] reasons, the conclusion - that the BEAT was not a treaty override - may be all that matters. If that was the working assumption of Congress, it would not have intended for the BEAT to override treaties.

Professors Rosenbloom and Shaheen then simply conclude that the BEAT does not provide a foreign tax credit limitation at all and do so without addressing the fact that Article 23 does not require such a reading and without answering why the BEAT is a covered tax. Thus, we do not believe that BEAT is a violation of Article 23, because (a) it may not be a covered tax, and (b) even if it is a covered tax, it is a limitation on the foreign tax credit that is consistent with its general principles of allowing a US tax credit against foreign taxes on foreign source income.

As for Article 24, we have explained elsewhere why we do not believe the BEAT violates non-discrimination. First, the BEAT applies to payments from US parents to foreign subsidiaries, so it is not limited to payments by foreign multinationals. This in our mind is the most important point because it means that both foreign and US multinationals are adversely affected by the BEAT. Second, the BEAT is not different from the old earnings stripping rule (IRC 163(j)) which is similar to the thin capitalization rules adopted by other countries, and is an accepted exception to non-discrimination that is needed to protect the US tax base. Third, the BEAT is not equivalent to a denial of a deduction because the BEAT rate is $10 \%$ and a denial of a deduction would have increased tax by $21 \%$. Finally, foreign related parties are simply not comparable to US related parties because the former are not subject to US taxing jurisdiction while the latter are. ${ }^{15}$

\section{The BEAT as a Treaty Override.}

Even if the BEAT were found to be inconsistent with US tax treaties, in our opinion it overrides them.

${ }^{15}$ Avi-Yonah, Reuven S., Beat It: Tax Reform and Tax Treaties (January 4, 2018). U of Michigan Public Law Research Paper No. 587; U of Michigan Law \& Econ Research Paper No. 18-003. Available at SSRN: https://ssrn.com/abstract=3096879 or http://dx.doi.org/10.2139/ssrn.3096 879; Wells, Bret, Get With the BEAT (February 19, 2018). Tax Notes, February 19, 2018, p. 1023.; U of Houston Law Center No. 2018-A-4. Available at

SSRN: https://ssrn.com/abstract=3143891. 
The U.S. position on treaty overrides can be summarized as follows. ${ }^{16}$ Under the U.S. Constitution, "Laws of the United States which shall be made in Pursuance thereof; and all Treaties made, or which shall be made, under the Authority of the United States, shall be the supreme Law of the Land."17 This "Supremacy Clause" was intended to ensure the supremacy of both U.S. federal laws and treaties to state laws, and was one of the major innovations in the Constitution.

On its face, the Supremacy Clause says nothing about the relationship between treaties and federal laws, and it is not at all clear whether it should ever have been interpreted as the basis for treaty overrides. However, the U.S. Supreme Court has for a long time held otherwise, deciding that under the Supremacy Clause treaties and laws are equal and therefore the principle of lex posterior (i.e., a later law abrogates a prior contrary law) prevails. ${ }^{18}$ In 1888 , in a case that discussed the relationship between a treaty that gave most favored nation status and a later statute imposing tariffs, the Court held that in resolving a clear conflict between a treaty and a federal statute, "[t]he duty of the courts is to construe and give effect to the latest expression of the sovereign will." ${ }^{19}$ And in 1957 the Court made its position even clearer, stating that "[a]n Act of Congress, which must comply with the Constitution, is on a full parity with a treaty, and ... when a statute which is subsequent in time is inconsistent with a treaty, the statute to the extent of conflict renders the treaty null." 20

The general U.S. rule is therefore that any statute that is later in time than a treaty, and that conflicts with it in some way, is a treaty override. This rule could have led to hundreds of tax treaty overrides each year, given the frequency of U.S. tax legislation. But even the Senate Report does not go so far, explaining that the courts generally strive to construe statutes to avoid treaty overrides: "[t]he cardinal rule is that repeals by implication are not favored. Where there are two acts upon the same subject, effect should be given to both if possible.... [T] he intention of the legislature to repeal must be clear and manifest."21 The same principle applies in the case of a treaty and a later statute: "When the two relate to the same subject, the courts will always endeavor to construe them so as to give effect to both, if that can be done without violating the language of either."22 "A treaty will not be deemed to have been abrogated or modified by a later statute unless such purpose on the part of Congress has been clearly expressed."23

${ }^{16}$ See generally Senate Report 100-445, 100th Cong., 2nd Sess., Tit. I, XII H. 1 (Relationship with Treaties), explaining sec. 112(aa) of S. 2238 (IRC sec. 7852) (the "Senate Report").

1718 U.S. Const. art. VI, cl. 2.

$181 \mathrm{~W}$. Blackstone, Commentaries *89.

19 Whitney v. Robertson, 124 U.S. 190, 195 (1888).

${ }^{20}$ Reid v. Covert, 354 U.S. 1, 18 (1957).

${ }^{21}$ Posadas v. National City Bank, 296 U.S. 497, 503 (1936).

${ }^{22}$ Whitney v. Robertson, 124 U.S. at 194.

${ }^{23}$ Cook v. United States, 288 U.S. 102, 120 (1933). 
However, the Senate Report also makes clear that when a clear conflict does exist, a treaty override will result: "Prior judicial efforts to find consistency between earlier and later statutes and treaties illustrate the difficulties of determining when application of the general later-in-time rule should result in giving effect only to the later provision; however, these difficulties cannot be permitted to obscure the fact that if an actual conflict does exist concerning a matter within the scope of both an earlier treaty and a later statute, as properly construed, the later statute prevails." 24

Moreover, this result obtains even where there is no evidence in the law or its legislative history that a treaty override was intended. The Senate Report's statement in this regard fully sets out the theory underlying the U.S. position, and it is thus worth quoting in full:

Notwithstanding Congress' intent that the [1986 Tax Reform] Act and income tax treaties be construed harmoniously to the extent possible, conflicts other than those addressed in this bill or in the Act ultimately may be found or alleged to exist. Similarly, conflicts between treaties and other acts of Congress affecting revenue are likely to be found or alleged to exist in the future, either with respect to existing or future treaties and statutes. The bill provides that for purpose of determining the relationship between a provision of a treaty and any law of the United States affecting revenue, neither the treaty nor the law shall have preferential status by reason of its being a treaty or a law. In adopting this rule, the committee intends to permanently codify (with respect to tax-related provisions) present law to the effect that canons of construction applied by the courts to the interaction of two statutes enacted at different times apply also in construing the interactions of revenue statutes and treaties enacted and entered into at different times. The committee does not intend this codification to alter the initial presumption of harmony between, for example, earlier treaties and later statutes. Thus, for example, the bill continues to allow an earlier ratified treaty provision to continue in effect where there is not an actual conflict between that treaty provision and a subsequent revenue statute (i.e., where it is consistent with the intent of each provision to interpret them in a way that gives effect to both). Nor does the committee intend that this codification blunt in any way the superiority of the latest expression of the sovereign will in cases involving actual conflicts, where that expression appears in a treaty or a statute... .

Although the committee believes that the bill's provision regarding the equal status of treaties and statutes merely codifies present law, the committee believes that this provision, and the bill's disclosure provision, are necessary technical corrections to the Act for several reasons. The

24 Senate Report, supra. 
committee is concerned that the relationship of the tax laws and treaties is misunderstood. The internal tax laws of most countries provide some sort of regime for taxing either the foreign income of domestic persons, the domestic income of foreign persons, or both. Either type of income, then, is potentially subject to two autonomous tax systems each of which is at best designed to mesh with other tax systems only in broad general terms. Double taxation of the same income, or taxation of certain income by neither system, can potentially result. Income tax treaties, in the committee's view, are agreements that provide the mechanism for coordinating two identified tax systems by reference to their particular provisions and the particular tax policies they reflect, and which have as their primary objectives is a desirable goal that serves to improve the long term environment for commercial and financial dealings between residents of the treaty partners.

The committee believes that when a treaty partner's internal tax laws and policies change, treaty provisions designed and bargained to coordinate the predecessor laws and policies must be reviewed for purposes of determining how those provisions apply under the changed circumstances. The committee recognizes that there are cases where giving continued effect to a particular treaty provision does not conflict with the policy of a particular statutory change. In certain other cases, however, a mismatch between an existing treaty provision and a newly-enacted law may exist, in which case the continued effect of the treaty provision may frustrate the policy of the new internal law. In some cases the continued effect of the existing treaty provision would be to give an unbargained-for benefit to taxpayers or one of the treaty partners. At that point, the treaty provision in question may no longer eliminate double taxation or prevent fiscal evasion; if not, its intended purpose would no longer be served.

The committee recognizes that some would prefer that existing treaties be conformed to changing U.S. tax policy solely by treaty renegotiation. However, the committee notes that in recent years, U.S. tax laws have been constantly changing. Moreover, once U.S. tax policy has changed, the existence of an unbargained-for benefit created by the change would have the effect of making renegotiation to reflect current U.S. tax policy extremely difficult, because the other country may have little or no incentive to remove an unbargained-for benefit whose cost is borne by the United States.

The committee recognizes that the parties to the treaty can differ as to whether the continued effect of a treaty provision in light of a particular statutory change provides such an unbargained-for benefit or otherwise frustrates the basic objectives of tax treaties. Remedies may be available in the case of what one party views as a breach of international law. However, the committee believes that under the constitutional system of 
government of the United States, where tax laws must be passed by both Houses of Congress and signed by the President, and where it is the role of the courts to decide the constitutionality of the laws and what the laws mean, it is not the role of taxpayers, the Judicial branch, or the Executive branch to determine that constitutionally valid statutes that actually conflict with earlier treaties ought not to be given effect either because of views of international law or for any other reason.

The committee is concerned that there are some who assert that treaties receive preferential treatment in their interaction with statutes. The committee is further concerned that whatever support is found for this view is based on misinterpretations of authoritative pronouncements on the subject. For example, before original introduction of this technical corrections legislation, the Internal Revenue Service announced that new Code section 367(e)(2), discussed above, which imposes corporate-level tax in certain liquidations, would not apply where it "would violate a treaty non-discrimination provision" (Notice 875, 1987-1 C.B. 416). Eventually, the Internal Revenue Service withdrew its notice on a prospective basis, and concluded that no treaty conflict existed (Notice 87-66, 1987-2 C.B. 376). The committee is concerned that the language used in the original notice may have suggested an erroneous inference that, had section 367(e)(2) actually created a conflict in a particular case, it would have been given no effect under the terms of the original Notice. Normal application of the later-in-time rule would not permit this result.

Other examples exist where the committee is troubled with erroneous inferences that have apparently been drawn from language used by the Executive branch. For example, in Revenue Ruling 80-223, 1980-2 C.B. 217, the Service considered the issue of whether foreign tax credit provisions enacted in the Tax Reduction Act of 1975 (sections 901(f) and 907) prevailed over conflicting provisions in earlier treaties that provide for foreign tax credits determined pursuant to the foreign tax credit provisions of the Code in effect as of dates specified in such treaties. The analysis stated the following:

In Cook v. United States, 288 U.S. 102 (1933), subsequent inconsistent legislation was held not to supersede an earlier treaty provision because neither the committee reports nor the debates on the subsequent legislation mentioned the earlier treaty. It is, therefore, necessary to examine the legislative history underlying the enactment of sections 901(f) and 907 of the Code for a clear indication from Congress as to whether it intended these sections to supersede any provision of treaties entered into prior to the enactment of these sections. 
The committee believes it would be erroneous to assert that the absence of legislative history mentioning a treaty was sufficient to reach the result in Cook. That case dealt with the question of how to construe an anti-bootlegger provision (section 581 of the Tariff Act of 1930) that first became law in an act (the Tariff Act of 1922) passed early on during Prohibition. Section 581 of the 1930 Act was a verbatim reenactment of section 581 of the Tariff Act of 1922. The scope of section 581 of the 1922 Act had been limited by a U.S.-Great Britain treaty made in 1924. The case came before the Supreme Court as Prohibition was in the last stages of being written out of the Constitution. The Court reached its conclusion on the stated ground that the treaty limit continued to apply under the 1930 Act, because section 581, "with its scope narrowed by the Treaty, remained in force after its re-enactment in the Act of 1930." 288 U.S. at 120 . Properly construed, therefore, the committee believes that Cook stands not for the proposition that Congress must specifically advert to treaties to have later statutes given effect, but that for purposes of interpreting a reenacted statute, it may be appropriate for some purposes to treat the statute as if its effect was continuous and unbroken from the date of its original enactment.

Similarly the committee believes it would be erroneous to assert that an income tax statute such as the Tax Reduction Act of 1975 prevails over treaties only if treaty interactions are mentioned in the statute or legislative history. On the other hand, the committee believes that any such mention, if made, would be dispositive.

In view of what the committee believes is the correct treatment of treaty-statute interactions, then, the committee finds it disturbing that some assert that a treaty prevails over later enacted conflicting legislation in the absence of an explicit statement of congressional intent to override the treaty; that it is treaties, not legislation, which will prevail in the event of a conflict absent an explicit and specific legislative override. The committee does not believe this view has any foundation in present law. Moreover, the committee believes that it is not possible to insert an explicit statement addressing each specific conflict arising from a particular act in the act or its legislative history; for in the committee's view, it is not possible for Congress to assure itself that all conflicts, actual or potential, between existing treaties and proposed legislation have been identified during the legislative process of enacting a particular amendment to the tax laws. In the absence of a clear statement that legislation prevails over prior treaties, dubious tax avoidance schemes, in the committee's view, have been suggested. See, e.g., Tax Notes, March 9, 1987, at 1004, improperly suggesting that the failure to clarify the relationship between the Subchapter S Revision Act of 1982 and earlier treaties allows foreigners to own and operate U.S. business taxfree. 
The committee believes that a basic problem that gives rise to the need for a clarification of the equality of statutes and treaties is the complexity arising from the interaction of the Code, treaties, and foreign laws taken as a whole. The committee notes that the United States has over 35 income tax treaties, some of extreme complexity, plus additional treaties bearing on income tax issues. In addition, the application of United States tax law to complex business transactions exacerbates these complexities. The committee does not believe that Congress can either actually or theoretically know in advance all of the implications for each treaty, or the treaty system, of changes in domestic law, and therefore Congress cannot at the time it passes each tax bill address all potential treaty conflict issues raised by that bill. This complexity, and the resulting necessary gaps in Congressional foreknowledge about treaty conflicts, make it difficult for the committee to be assured that its tax legislative policies are given effect unless it is confident that where they conflict with existing treaties, they will nevertheless prevail.

The committee further believes that codification of this rule, together with the disclosure requirements in the bill, will lead to the early discovery of now-unknown treaty conflicts and to their appropriate resolution. If any case actually arises in which proper application of the canons of construction ultimately reveals an actual conflict, the committee expects that full legislative consideration of that conflict will take place to determine whether application of the general later-in-time rule is consistent with the spirit of the treaty (namely, to prevent double taxation by an agreed division of taxing jurisdiction, and to prevent fiscal evasion) and the proper expectations of the treaty partners. ${ }^{25}$

Against this strong legislative history, it is hard to argue, as Rosenbloom and Shaheen do in reliance on Cook, that the absence of a clear statement of Congressional intent means that the BEAT does not override treaties. If this were presented to a court, in our opinion the court would not find the BEAT to be a treaty violation for the reasons stated above. But if the court were to consider the BEAT a treaty violation, it is hard to envisage it as concluding that the treaties should defeat the clear intent of the BEAT, which is to protect the US tax base by limiting the affected deductions and to not allow a foreign tax credit against the

25 Senate Report, supra (emphases added). The above legislative history for tax legislation is consistent with broader scholarship on how unambiguous later-intime legislation should be understood as overruling earlier treaty provisions. See Andrew H. Bean, Constraining Charming Betsy: Textual Ambiguity as a Predicate to Applying the Charming Betsy Doctrine, 2015 B.Y.U. L. Rev. 1801 
BEAT. Certainly, Mr. Barthold's ambiguous statement cannot be relied on for this purpose since he is not a member of Congress. ${ }^{26}$

Moreover, allowing treaties (and especially the non-discrimination article) to overcome the BEAT would be to completely defeat the purpose of the legislation. Any taxpayer would be able to re-structure their affairs so that payments that are covered by the BEAT would be made to affiliates resident in treaty countries, and soon the BEAT would have no bite at all.

Perhaps most relevant to this discussion is the substantial line of US cases that have addressed the predecessor to Section 59A and its interpretation with existing US treaties, namely old Section 59. In Kappus v. Commissioner, 337 F.3d 1053 (D.C. Cir., 2003), the Court of Appeals addressed old Section 59's restriction on the ability to use foreign tax credits under the predecessor to Section 59A's alternative minimum tax regime. In Kappus, the Court of Appeals held unanimously that the $90 \%$ limitation on the foreign tax credit enacted by the Tax Reform Act of 1986 overrode the US Canada Tax Treaty (1984) despite the absence of evidence of Congressional intent to override in the legislative history of the 1986 act. $^{27}$ The court held that:

The question of whether the Treaty and statute can be harmonized as the government suggests is an extremely close one. It is not, however, a

${ }^{26}$ A stronger indication of Congressional intent may be derived from (a) the question posed to Mr. Barthold, which suggests that Congress intended the BEAT to apply even if it were a treaty override, (b) a hearing of the Senate Finance Committee on October 3, 2017, in which one of us testified to the urgent need to protect the US tax base even if it meant overriding the treaties. The US has a long history of treaty overrides. See, e.g., IRC section 897 (FIRPTA), 884 (branch profit tax, which overrode treaties by applying the "qualified resident" rule), 894(c), and 163(j) (which despite its nominal application to tax exempt related parties was universally understood to apply only to foreigners and thus arguably to override article 24(4)). See generally Avi-Yonah, Reuven S., Tax Treaty Overrides: A Qualified Defense of Us Practice (October 12, 2005). Available at SSRN: https://ssrn.com/abstract=829746 or http://dx.doi.org/10.2139/ssrn.82974 $\underline{6}$.

27 Kappus v. Commissioner, 337 F.3d 1053 (D.C. Cir. 2003). In Owner-Operator Independent Drivers Ass'n, Inc. v. United States Departmentof Transportation, No. 12-1264 (D.C. Cir. 2013), the DC Circuit refused to allow a general statute requiring truck drivers to have a medical certificate to override an earlier executive agreement with Mexico exempting Mexican drivers from such a requirement absent clear evidence of Congressional intent. We think this case is distinguishable, because there was no indication Congress considered the Mexico executive agreement when it enacted the general statute, while in the case of BEAT, Congress clearly was aware of the potential override issue presented by the BEAT, given the question Barthold answered. 
question that we need resolve. The Kappuses concede that, even if their reading of the Treaty is correct and the Treaty and $\S 59(a)(2)$ are in irreconcilable conflict, the statute nonetheless would control their tax liability if it were the most recent relevant provision. Accordingly, because we conclude in Part III that the statute is in fact the last relevant provision, we need not further pursue the search for harmony. See South African Airways v. Dole, 817 F.2d 119, 125-26 (D.C.Cir.1987) (assuming arguendo the existence of a conflict between a treaty and a statute, and resolving the case on the basis of the last-in-time principle); Jamieson v. Comm'r of Internal Revenue, 70 T.C.M. (CCH) 1372, 1373-74 (Tax Ct.1995) (holding, in a case prior to the amending protocols, that $\S$ 59(a)(2) prevailed over the U.S.-Canada Tax Treaty under the last-in-time principle without determining whether they were in conflict), aff'd, 132 F.3d 1481 (D.C.Cir.1997).

It is true that the court relied in part on a general clarification in TAMRA (1988) that Congress intended to override the treaties when enacting 1986 act. But that clarification was not specific to the $90 \%$ limit, and in any case was subsequent to the 1986 act and not part of its legislative history. Thus, Kappus stands for the proposition that when a conflict between a treaty and a statute clearly exists, the latter in time rule is dispositive even in the absence of legislative history, and even when the override is a clear violation of the spirit of the treaty (which in our opinion the BEAT is not).

Professors Rosenbloom and Shaheen fail to address the holding of Lindsey v. Commissioner, ${ }^{28}$ albeit they do cite this case in a string cite. In Lindsey v. Commissioner, the Tax Court was confronted with whether the alternative minimum tax regime under Section 59 that did not allow for full usage of US foreign tax credit relief violated the U.S. treaty obligations to provide double tax relief under the Canadian treaty. The taxpayer urged the court to harmonize the manner of Section 59's application so that it would not restrict the usage of US foreign tax credit relief. The Tax Court rejected that invitation, and it applied old Section 59 without adjustment claiming that the later in time rule applied. ${ }^{29}$ Given this holding with respect to the predecessor alternative minimum tax regime under old Section 59, it is difficult to imagine that the Tax Court would use logic it rejected in Lindsey to find that the successor Section 59A could not be applied without restriction as an override to any previously enacted treaty obligation.

To conclude: Contrary to Rosenbloom and Shaheen, for purposes of calculating the BEAT, deductions for otherwise deductible payments to related persons resident in treaty countries and foreign tax credits for foreign taxes paid

\footnotetext{
28 See Lindsey v. Commissioner, 98 T.C. 672 (1992).

${ }^{29}$ See Lindesy v. Commissioner, 98 T.C. 672 (1992) aff'd mem (15 F.3d 1160 (D.C. Cir. 1994). Professors Rosenbloom and Shaheen fail to explain why this prior law do not sufficiently answer their objections with respect to the interpretive issues under the successor alternative minimum tax regime now contained in Section 59A.
} 
to treaty countries should not be allowed. Any argument to the contrary is inconsistent with the clear Congressional purpose of enacting the BEAT, which was to protect the US tax base from inflated deductions paid to related foreign parties that are not subject to US tax jurisdiction. 